NBER WORKING PAPER SERIES

\title{
ECONOMIC ANALYSIS OF \\ THE GENERAL STRUCTURE OF THE LAW
}

\author{
Steven Shavell \\ Working Paper 9699 \\ http://www.nber.org/papers/w9699 \\ NATIONAL BUREAU OF ECONOMIC RESEARCH \\ 1050 Massachusetts Avenue \\ Cambridge, MA 02138 \\ May 2003
}

Research support from the John M. Olin Center for Law, Economics, and Business is gratefully acknowledged. The views expressed herein are those of the authors and not necessarily those of the National Bureau of Economic Research.

(C)2003 by Steven Shavell. All rights reserved. Short sections of text not to exceed two paragraphs, may be quoted without explicit permission provided that full credit including Cnotice, is given to the source. 
Economic Analysis of the General Structure of the Law

Steven Shavell

NBER Working Paper No. 9699

May 2003

JEL No. D00, D8, K00, H00

\title{
$\underline{\text { ABSTRACT }}$
}

This paper contains a chapter on the general structure of the law from a forthcoming book, Foundations of Economic Analysis of Law (Harvard University Press, 2003). In this chapter, I consider basic features of the legal system, including whether the law directly constrains behavior or channels it by the threat of sanctions, and whether the law is brought into play by private legal action or involves public enforcement. I investigate the conditions under which one or another structure of law will be socially desirable, and I then discuss tort, contract, criminal law, and several other areas of law in the light of the analysis of the optimal structure of the law.

\author{
Steven Shavell \\ Harvard Law School \\ 1575 Massachusetts Avenue \\ Hauser Hall 508 \\ Cambridge, MA 02138 \\ and NBER \\ shavell@law.harvard.edu
}


Table of Contents

Economic Analysis of the General Structure of the Law

(part of Foundations of Economic Analysis of Law)

Chapter 25. The General Structure of Legal Intervention and Its Optimality

1. Fundamental Dimensions of Legal Intervention

2. Optimal Structure of Legal Intervention

3. Optimal Structure of Legal Intervention Illustrated

4. Remarks: Incompleteness of Analysis 


\title{
Summary Table of Contents
}

\section{Economic Analysis of the General Structure of the Law}

\author{
(part of Foundations of Economic Analysis of Law)
}

Chapter 1. Introduction

Part One. Property Law

Chapter 2. Definition, Justification, and Emergence of Property Rights

Chapter 3. Division of Property Rights

Chapter 4. Acquisition and Transfer of Property

Chapter 5. Conflict and Cooperation in the Use of Property: The Problem of Externalities

Chapter 6. Public Property

Chapter 7. Property Rights in Information

\section{Part Two. Accident Law}

Chapter 8. Liability and Deterrence: Basic Theory

Chapter 9. Liability and Deterrence: Firms

Chapter 10. Extensions of the Analysis of Deterrence

Chapter 11. Liability, Risk-bearing, and Insurance

Chapter 12. Liability and Administrative Costs

\section{Part Three. Contract Law}

Chapter 13. Overview of Contracts

Chapter 14. Contract Formation

Chapter 15. Production Contracts

Chapter 16. Other Types of Contract

Part Four. Litigation and the Legal Process

Chapter 17. Basic Theory of Litigation

Chapter 18. Extensions of the Basic Theory

Chapter 19. General Topics on the Legal Process

Part Five. Public Law Enforcement and Criminal Law

Chapter 20. Deterrence with Monetary Sanctions

Chapter 21. Deterrence with Nonmonetary Sanctions

Chapter 22. Extensions of the Theory of Deterrence

Chapter 23. Incapacitation, Rehabilitation, and Retribution

Chapter 24. Criminal Law

Part Six. General Structure of the Law

Chapter 25. The General Structure of Legal Intervention and Its Optimality

Part Seven. Welfare Economics, Morality, and the Law

Chapter 26. Welfare Economics and Morality

Chapter 27. Implications for the Analysis of Law

Chapter 28. Income Distributional Equity and the Law

Chapter 29. Concluding Observations about the Economic Analysis of Law 


\title{
Chapter 25
}

\section{THE GENERAL STRUCTURE OF LEGAL INTERVENTION AND ITS OPTIMALITY}

\author{
Steven Shavell
}

(C) 2003. Steven Shavell. All Rights Reserved.

In this chapter, I will consider the general structure of the law, by which I refer to the answers to such questions as the following. Does the law directly constrain behavior, or does the law employ the threat of imposition of sanctions to channel behavior? If sanctions are utilized, are they applied whenever behavior is judged undesirable or only when behavior results in harm? Is the law initiated by the legal actions of private parties or does it involve public enforcement?

These questions are implicitly answered in one way by the law that we observe. Under tort and contract law, for example, the legal system is triggered only by the occurrence of harm, namely, by a tort or a breach of contract, whereas under criminal law, the legal system comes into play and sanctions may be imposed even if harm is not done, notably, when individuals commit attempts; and under property law the legal system may intrude before harm is done, such as when dangerous behavior is enjoined. Enforcement of tort and contract law is essentially private in nature, whereas criminal law is publicly enforced. And so on.

Such differences in the structure of our major subject areas of law lead us to ask what the socially advantageous structure of law might be, in what respects the structure that we observe can be rationalized, and in what respects it may deviate from the desirable structure. Below, I will examine a relatively simple theory of the determinants of the answers to these questions, and I will subsequently consider briefly tort and contract law, safety regulation, the injunction, and criminal law in the light of the analysis of optimal general structure of the law. ${ }^{1}$

\section{Fundamental Dimensions of Legal Intervention}

Here I discuss three primary dimensions of legal methods of controlling behavior and then describe major areas of law in terms of these basic dimensions.

1.1 Time of intervention: before acts, after acts, after harm. The time of legal intervention is a primary dimension of a means of controlling behavior. Intervention may occur before an act is committed, usually by means of outright prevention of the act. Examples include fencing in a reservoir to prevent people from polluting it, denial of authority to operate a nuclear

\footnotetext{
${ }^{1}$ This chapter follows the general outline of Shavell 1993.
} 
power plant to prevent harm from use of the plant, the exercise of force to stop a person from shooting another, and imprisoning an individual to prevent him from committing bad acts.

A second time of legal intervention is after an act has been committed but before harm occurs (or independently of whether it occurs). Such intervention involves the use of sanctions triggered by the commission of acts. If society punishes a person for shooting at another person regardless of whether he hits him, it is imposing a sanction based on the commission of the act of shooting. Likewise, if society employs a safety regulation requiring that sprinklers be installed in a hotel and the hotel operates without them and is fined (regardless of whether a fire occurs), society is imposing a sanction based on an act. In neither case, note, is society preventing undesirable acts directly; rather, society is attempting to deter the acts by the threat of sanctions for committing them.

The third time of legal intervention is after harm has occurred, by means of harm-based sanctions. This is the method of tort law, or of fines based on harm done. Also, in criminal law, harm-based sanctions are often imposed (if a person murders someone, he will be punished more severely than if he only attempted murder).

Comment. The model that $\mathrm{I}$ have in mind in making the distinctions above is such that a party can choose to commit a single act, like shooting a gun at someone. A more detailed model would allow for parties to commit multiple acts, such as brandishing a gun and then shooting it. In such a model, the description of legal intervention would be more refined; for example, what I call prevention in the simple model might correspond to prevention of one type of act (shooting a gun) based on a party committing another type of act (brandishing a gun). However, the basic thrust of the analysis of such more complex models would not be different from that of the analysis below of the simple model.

1.2 Form of intervention: prevention or sanction (and its type). The form of legal intervention may involve a method of preventing an act from occurring, typically through use of force (as when a police officer takes a gun away from a person or when a regulatory authority locks the doors of a power plant) or physical barriers (as when a reservoir is fenced in to prevent intrusions). A second major form of intervention is the imposition of sanctions, notably, of monetary sanctions or of imprisonment. ${ }^{2}$

1.3 Privately versus publicly initiated intervention. The use of the legal system may be instigated only when a private party asks for that to occur, such as when a person brings a tort suit or seeks an injunction; this constitutes private enforcement of law. The legal system may also be brought to bear when the state's enforcement agents determine that it is appropriate, such as when police officers or tax collection agents find violations of law and sanction them. (In the latter case, the state's agents may obtain information from private parties who volunteer it, but I shall for the most part ignore that point for present purposes.)

1.4 Methods of legal intervention described in terms of fundamental dimensions. It may be helpful to consider a matrix describing certain areas of law and commonly employed legal methods of control (the matrix is obviously not intended to be exhaustive) in terms of the three dimensions of legal intervention just mentioned.

\footnotetext{
${ }^{2} \mathrm{~A}$ reward can be interpreted as a negative sanction, so is implicitly included as a possible sanction.
} 
Methods and Dimensions of Legal Intervention

\begin{tabular}{|l|l|l|l|}
\hline \multirow{2}{*}{$\begin{array}{l}\text { Method of Legal } \\
\text { Intervention }\end{array}$} & \multicolumn{3}{|l|}{ Fundamental Dimensions of Legal Intervention } \\
\cline { 2 - 4 } & Time of intervention & Form of intervention & Private versus public \\
\hline tort law & after harm & monetary sanctions & private \\
\hline safety regulation & before and after acts & various & public \\
\hline injunction & before and after acts & various & private \\
\hline contract law & after harm & $\begin{array}{l}\text { monetary } \\
\text { sanctions;other }\end{array}$ & private \\
\hline criminal law & $\begin{array}{l}\text { before and after acts; } \\
\text { after harm }\end{array}$ & various & public \\
\hline
\end{tabular}

The entry on tort law is self-explanatory. I describe safety regulation as applying both before and afer acts occur because sometimes safety regulation functions through preventing certain acts from being committed, as when a restaurant is not allowed to open its doors unless it has passed a safety inspection, and at other times, regulation works through imposition of sanctions in response to a person's violation of regulation, as when a person is given a ticket for going through a stop sign or a restaurant is penalized for failing to clearly mark exits. I also describe the form of intervention under regulation as various because, as just mentioned, acts can be prevented, and also they can result in sanctions, including nonmonetary ones.

The injunction is similar to safety regulation in that it can be employed to prevent a dangerous act (usually after some prior behavior suggesting danger) or it can be a consequence of a potentially or actually dangerous act (as when a person who has ferocious dogs as pets is enjoined from keeping them). The main difference from safety regulation is that the injunction is brought by private parties.

Contract law, like tort law, is a method of legal intervention that generally applies only after harm is done, when there is a breach of a contractual obligation, and it is private in that private actions must be brought for relief. The form of intervention is usually damages for breach, but may also involve specific performance, which is to say, use of methods, possibly including the police powers of the state, to enforce contractual obligations, such as the conveyance of land.

Criminal law, as indicated in part above, is employed before certain acts occur in order to prevent them, as well as after they occur and after harm is done. The form of intervention is not only prevention but also includes monetary and nonmonetary sanctions, and enforcement of criminal law is public.

\section{Optimal Structure of Legal Intervention}

The state has to choose methods of legal intervention to control behavior, and in order to analyze 
the optimal means of intervention, I will first define the social welfare criterion and then discuss the optimal choice of each of the three primary dimensions of the means of intervention. This will allow us to organize our thinking about the determinants of the optimal structure of legal intervention.

2.1 Social welfare criterion. The measure of social welfare will for simplicity be taken to be the benefits individuals obtain from acts minus the harms done and the costs of enforcement of law. ${ }^{3}$ These costs include the costs of identifying parties to whom sanctions ought to apply, the costs of applying the law, and also the costs of imposing sanctions. When the sanctions are monetary, I will generally assume that there is little expense associated with their actual imposition. This is motivated by the point that the imposition of monetary sanctions amounts to a transfer of purchasing power, not a use of resources (see the discussion in chapters 20 and 21). When the sanction is imprisonment, I will assume that there is substantial social cost associated with its imposition, for imprisonment absorbs social resources.

2.2 Determinants of the optimal time of intervention. There are several factors that bear on the socially optimal time of legal intervention.

Information about the character of acts possessed by the state versus information possessed by private parties. As a general matter, it appears that the worse is the knowledge possessed by the state about the dangerousness of parties' acts relative to the knowledge of the parties themselves, the more attractive will be legal intervention that occurs at later stages. If the state knows relatively little about the harmfulness of an act, then sanctions based on the occurrence of harm and its magnitude will be appealing, for harm constitutes evidence of dangerousness, whereas appropriate sanctions based on acts alone will be difficult for the state to determine. If the state does not know how dangerous it is to leave a live wire exposed (because the state does not know the likelihood that someone would step on it), a sanction based on harm resulting from that act will be more attractive than a sanction based only on commission of the act. Likewise, if the state does not know the particular nature of the act a person is likely to commit, only its general character, a sanction based on the commission of acts will be more attractive than prevention of a whole class of possible acts. If the state does not know whether a person will draw his gun and threaten another, it may be best not to prevent the category of acts, carrying guns, but only to sanction those persons who commit the act of brandishing their weapons in a menacing way.

If, rather than private parties possessing superior information to the state, it is the state that enjoys superior information, then the conclusions just discussed are reversed: Earlier legal intervention will become more attractive than later. If the state, but not a person, knows that a certain insecticide is carcinogenic, then the state might prefer to prevent its use through regulation, because the threat of sanctions based on expected danger from its use or on harm caused would tend to be ineffective. Note, though, that an alternative for the state would be for it to inform individuals of danger, in which case there would be no reason for early legal intervention. However, in some circumstances, communication is not possible or is costly.

Effectiveness and feasibility of sanctions. The effectiveness of sanctions depends on the likelihood that they will be applied and on their feasible magnitude. If sanctions will not be

\footnotetext{
${ }^{3}$ The significance of various omissions from the social welfare criterion will be briefly noted at the end of the chapter.
} 
applied with high likelihood because individuals who commit undesirable acts or who cause harm cannot easily be identified, sanctions will not be very effective. And if feasible sanctions will not be high, as would be the case if they are monetary but a person has little wealth, they would again be limited in effectiveness.

As a general matter, sanctions are disfavored, and prevention of acts is attractive, when sanctions are sufficiently lacking in effectiveness. If it would be difficult to catch a person who pollutes a reservoir, the best method for controlling this undesirable behavior may be to prevent it by fencing in the reservoir. Similarly, use of an injunction may be the best method to control the behavior of a firm that could cause large harm by its activities and that possesses little in assets, as it would not be deterred much by the threat of a monetary penalty.

When sanctions increase in effectiveness, act-based and harm-based sanctions may become useful. In this regard, note that act-based sanctions do not require that sanctions be as high as harm-based sanctions, if the harm due to an act is probabilistic. To illustrate, consider money sanctions and the possibility that a person may not be able to pay for harm done, so that he would not be adequately deterred by fear of such sanctions for doing large harm. Yet sanctioning him for his act may still be effective, for the sanction necessary to deter him may be much lower. Suppose that a person's act would cause harm of 1,000 with probability 10 percent, that is, expected harm of 100, and would yield him a benefit of only 50, so that his act is undesirable. If society relies on an ex post sanction, imposed only if harm occurs, the person will not be deterred unless his assets are at least 500, for $10 \% \mathrm{H} 500$ is 50 . But if society imposes a certain sanction for his act of only 100 -- the expected harm caused by it -- the individual will be deterred as long as he has assets of at least 50. A party needs to have much higher assets to be deterred by the threat of sanctions for doing harm than by the threat of sanctions for committing an act, if the act causes harm only with a low probability.

In summary, then, ineffectiveness of sanctions may lead to the desirability of prevention over sanctions for acts or for harm, and also to the appeal of act-based over harm-based sanctions.

Administrative cost. There may be substantial variations in the cost society bears if it employs different methods of intervention at one or another time. For example, it may be that prevention of some types of act is relatively cheap, compared to policing the acts or the harm due to them. To stop people from entering a reservoir, all that is needed is a fence; this may be much less expensive than stationing police around the reservoir to catch polluters and then imposing sanctions. When prevention can be accomplished by use of a physical barrier, whereas sanctioning would require monitoring to see when an act or harm is done, prevention may be economical. In other circumstances, prevention may be more expensive than the use of sanctions. To ensure that people behave correctly when driving, society could place a police officer next to the driver inside each car and have the officer stop the driver from making improper turns, speeding, and the like. But this prevention of bad driving would be absurdly expensive. As a far cheaper alternative, society uses sanctions to penalize bad driving and the harm in which it results.

With regard to act-based versus harm-based sanctions, administrative costs are also relevant. Harm-based sanctions have an underlying advantage in that they are applied only with a probability, since acts often do not result in harm. This makes harm-based sanctions cheaper, other things being equal, although act-based sanctions are sometimes more easily imposed. 
2.3 Determinants of the optimal form of intervention. With regard to the choice between forms of sanctions, what was discussed earlier in chapter 21 applies, namely, that sanctions should tend to be employed in the order of their cost. This means that monetary sanctions should be employed first, and then imprisonment only after monetary sanctions cannot be used because a person's wealth has been exhausted. (This point was subject to some qualifications, such as that monetary sanctions will not serve to achieve incapacitation, but these qualifications need not detain us here.) With regard to the use of sanctions to discourage acts versus the prevention of acts, the cost element also comes into play, as just mentioned in section 2.2 , for sanctions may be cheaper than prevention, or the converse.

2.4 Determinants of the optimality of private versus public enforcement. Whether it is advantageous for legal intervention to come about through legal actions brought by private parties or through efforts of public enforcement agents depends on which method most economically results in the identification and, if necessary, the apprehension, of the parties to whom the law should apply. In answering this question, in turn, it is useful to consider whether or not private parties naturally hold information about the identity of violators, that is, those to whom the law should apply.

Private parties naturally possess information about the identity of violators. Suppose that victims or potential victims of harm from dangerous acts, or perhaps other parties, can identify the violators with little or no effort. Then a private role in law enforcement is apparently desirable, for it is advantageous for society to harness this information that private parties have rather than to spend resources on public enforcement to uncover violations.

To avail itself of victims' information, society must provide them with an incentive to report their information to social authorities. One way to furnish victims an incentive to report is to give them a monetary gain for so doing. Notably, if victims can sue for harm that they sustain, as they do under tort and contract law, they will have a motive to report harm that they suffer. Another possibility is that victims can be paid rewards by the state, rather than by those who injured them. Victims may also be motivated to report violators in order to obtain retributive satisfaction, presuming the violators will be sanctioned. Additionally, potential victims may be led to report violators in order to avoid future harm, as when a person brings an injunction to stop a dangerous activity that could cause him to suffer losses. Through these various means, society can induce victims and potential victims to report violations when the victims know the identity of the violators.

In some contexts, private parties other than victims will have information about violators, for they will witness violators' actions, such as when a person observes a hit-and-run automobile accident or knows that someone has violated the tax laws. When such parties have information about violations, financial incentives to report can be provided, usually rewards of some type. However, these parties' motives to collect may often be less strong than those of victims who have suffered loss. Also, these parties are less likely to obtain retributive satisfaction from reporting violations than would victims. Additonally, these parties do not usually benefit personally from halting an ongoing dangeorous activity, unlike victims and potential victims. Consequently, the task of providing incentives to report is, in an approximate sense, more difficult when it is parties other than victims and potential victims who possess information about violations.

A possible difficulty connected with payment of money to private parties for reporting 
violations is that of false assertions of violations, as where a person sues for losses that he did not sustain, or an individual illegitimately claims that he observed another person speeding on the highway. To combat this problem, the state needs to be able to verify the validity of reported violations, and the ability to do this will vary. If a person sues for losses that he did not really sustain, it may be fairly easy to determine whether the losses were suffered because normally there will be evidence of loss; but if a person is reported to have sped, it is not clear that that can be verified. Where the problem of verification is serious, the use of financial incentives to obtain reports of infractions will be compromised. ${ }^{4}$

Effort must be expended to identify or to apprehend violators. When the identification or apprehension of violators is difficult and requires effort, public enforcement activity by enforcement agents may be required. If private parties are unlikely naturally to be able to spot and identify violators, such as those who discharge pollutants into a lake or those who speed on the highway, then public enforcement effort may be needed to identify them. Even if a private party knows the identity of a violator, such as who it was that stole something, it might not be easy to locate that person, again possibly calling for public effort.

This point, that when effort is required to identify or apprehend violators, public enforcement agents may be needed, requires amplification and qualification. The main reason is that it might be that private parties could be provided with a motive to identify and apprehend violators by being paid bounties for so doing. This, however, raises a number of difficulties. One is that payment of bounties may engender false accusations (similar to the problem just mentioned of false accusations if victims are rewarded for reporting violations). Another difficulty is that the incentive of private parties to find violators might be excessive for reasons analogous to that why fishing effort is excessive (when one person devotes effort to finding a violator, he does not take into account that he lowers the likelihood that others will find them). A more general issue is that there are many respects in which efficient effort to identify and apprehend violators requires coordination and, sometimes, investment in information systems (such as fingerprint records). A different problem with payment of bounties is that the social interest might not be served by maximizing bounty income, for the reduction in the number of violations is society's ultimate interest, yet this would reduce bounty income. The import of these various problems associated with payment of bounties is that public enforcement may hold out advantages over private. Another possible implication is that, if private enforcement is desirable, it would probably have to be accomplished by large enterprises, and perhaps by regulated monopolies that would be rewarded not only by bounties but also for reducing the number of harmful acts. In any case, what is important for us is not so much whether enforcement by a public agency is best, but that the enforcement activity must be undertaken by a large organization that has the basic characteristics of public enforcement organizations: It has a hired corps of enforcement agents, who work in a coordinated way on a large scale to apprehend violators, and its interest is not only in penalizing violators but also in deterrence. I

\footnotetext{
${ }^{4}$ Of course, public enforcement involves similar problems: A public enforcement agent might frame a person to collect a reward for turning him in, or in order to extort money from him in exchange for not turning him in. However, the methods available to control this problem are different from those available to control false reports by private parties (for instance, a police officer who observes speeding can be required to turn in an electronic record of a radar gun that clocked speed; his bank accounts can be monitored for extra income, and the like).
} 
will refer to this organization of enforcement as public enforcement for simplicity.

Conclusion. The above discussion suggests that when private parties themselves, and especially victims, can naturally identify violators, private parties will often be desirable to use in law enforcement in order to harness their socially valuable information. But when effort is required to identify or apprehend violators, it will often be desirable to employ public enforcement agents to enforce the law.

\section{Optimal Structure of Legal Intervention Illustrated}

I will now illustrate the analysis of the optimal structure of the law by considering important areas of legal intervention, and will suggest that the characteristics of the legal regime that we observe are rational in an approximate sense. I will also examine the possibility of beneficial changes in the overall design of the legal system in the light of the foregoing theory about its optimal structure. I should say at the outset that much of the discussion of this section is of a frankly conjectural nature, and is motivated mainly by a desire to demonstrate the value of analyzing the gross structure of the law from an economic perspective.

3.1 Tort law. Consider the usual type of tort, such as a car accident, or an injury caused when an object falls from a crane at an urban construction site and injures a person walking by. ${ }^{5}$ The question to be addressed is why is it socially advantageous for the behavior giving rise to such harms to be controlled by means of a method of legal intervention with the characteristics of the tort system, namely, a system that imposes monetary sanctions when harm is done, and when private parties sue to collect?

A speculation about the answer is as follows. First, the use of just monetary sanctions for harm leads to reasonably good incentives to reduce harm in the domain of tort, for the identity of the responsible party is known to the victim -- this would be often be true in a car accident, or if an object is let go by a crane -- and the responsible party often has assets or liability insurance coverage sufficient to pay for the harm. This is hardly to deny that incentives may be diluted by victims' inability to determine the authors of harm and by the judgment-proof problem. But these problems do not seem to be great enough in the general domain of tort to make resort to imprisonment advantageous as a sanction. If society were to imprison individuals for causing automobile accidents of the usual tortious nature, for harms caused when objects drop from cranes, and for the whole range of torts that we experience, the costs of this much more expensive form of sanction would be enormous and essentially unbearable.

To continue, if society were not usually to limit sanctions in the area of tort to occasions when harm occurs, but instead were to penalize potentially harmful acts or attempt to prevent them, it would encounter serious informational problems and incur staggering administrative costs. Society would have to identify which behavior was really dangerous enough to warrant sanctions. Given the great mass of behavior that could result in tortious harms (including the millions of daily instances of bad driving, failure to clear sidewalks of ice, and so on), the task of sorting out which behavior is dangerous enough to be punished could not be performed well. The courts would not know enough to be able to do that; and note that determining whether behavior that has not resulted in harm is really dangerous is more difficult than evaluating behavior that

\footnotetext{
${ }^{5}$ I restrict attention in this section to unintentional torts.
} 
has resulted in harm. Moreover, the volume of cases that would have to be considered would be a large multiple, plausibly at least a thousand times larger than the volume of torts cases, for the simple reason that most dangerous behavior does not actually result in harm. Society saves greatly under the tort system because it engages the legal apparatus only in those instances in which harm eventuates.

It remains to say why it makes sense for private parties to have the role that they do under the tort system, that is, for sanctions to be imposed only when private parties sue and for the parties to collect the sanctions. The explanation is that in the circumstances of the usual tort, the victim knows or can readily ascertain the identity of the injurer. When a person is injured in a car accident or by an object that falls from a crane, as mentioned above, the victim will usually know or be able to learn easily who the injurer was. (Indeed, if this is not the case because the injurer attempts to conceal his identity, as in a hit-and-run accident, the injurer's act may be treated as a crime, and thus public enforcement will be employed to raise the likelihood of identifying him.) If the victims generally know or can learn the identity of their injurers, then, as I suggested above, they can be and will be led to initiate legal intervention by being allowed to collect the money sanction. Granting victims the right to sue and collect damages leads to the identification of injurers, and importantly, to the supply of information about their behavior that society would otherwise not be able to obtain or would have to spend to determine. If the state had to monitor the number of automobile accidents and impose fines for harm done, but victims would not collect as a consequence, how often would victims report the accidents, testify, and otherwise provide information about their harm and about the behavior of injurers? The private nature of the tort system, with the reward of damages paid to victims, allows society to enjoy the benefit of the knowledge that victims naturally acquire about the identity and behavior of injurers.

3.2 Safety regulation. Consider now types of behavior that classically are regulated: use of materials and devices influencing fire risks, elevator maintenance, the making and preparation of foods and drugs, the building and operation of nuclear reactors, and so forth. Here the question at issue is why we should control such behavior by means of regulation, which is to say, by prevention and act-based sanctions using public enforcement? ${ }^{6}$

With regard to the fact that the stage of intervention is before harm occurs, I surmise that reliance on harm-based sanctions would not be adequate to control much of the behavior under discussion. Where safety regulation is employed, it seems that the magnitude of possible harms is often large in relation to the assets of the actor. A fire at a movie theatre could kill many people, substantially exceeding the assets of the theatre owner; a nuclear power plant accident could cause vast harm, injury to tens of thousands of individuals, greatly exceeding the assets of its owner; and likewise with contaminated food and its producer or preparer. Moreover, in some cases, there would be difficulty in identifying the party who caused harm; the long-term harm generated by a nuclear leak might be hard to ascribe to the accident, due to the multiplicity of possible causes of certain cancers; food poisoning might be hard to trace to its origin.

If harm-based sanctions are inadequate to control harm, and prevention and act-based sanctions become appealing, society confronts the general problem that it needs to determine which behavior is really dangerous. In the areas of safety regulation, it appears that we have

${ }^{6}$ This behavior is also controlled by tort law, in that if it results in harm, tort cases may usually be brought; see section 3.6 below. 
attempted to meet this problem by limiting the scope of regulation to those behaviors that we can say with fair confidence are undesirable. When regulating fire safety, we concern ourselves with such actions as the marking of fire exits and the installation of sprinkler systems, where it is not difficult for society to make a judgment about benefits and costs. Normally, society does not regulate safety where what is at issue is details of behavior, such as how much wood is stored in the basement of a hotel, because it is harder for a regulator to make a sound judgment about something like this than about whether there ought to be a sprinkler system in the hotel.

Society also tends to conserve the administrative costs of act-based intervention and prevention by such techniques as focusing on installation of devices that are easy to check (such as sprinkler systems) rather than on modifiable behavior (whether barbecue grills are used in a safe way), because that would often entail expensive, continuous monitoring; and when behavior is regulated, administrative cost savings are sometimes obtained by use of random monitoring.

Additionally, society sometimes uses methods of prevention of undesirable behavior when that is inexpensive. Consider the example mentioned of fencing off a reservoir. Or consider the use of a tollgate at the entrance to a tunnel to prevent oversize vehicles or ones carrying hazardous materials from entering. In such instances, prevention is cheap, and by its nature does not rely on incentives to stop undesirable behavior.

The form of sanction employed in safety regulation, when methods of prevention are not employed, is often monetary because, as mentioned in section 2.2, act-based sanctions may not need to be very high to induce desired behavior. To induce a firm to install fire extinguishers costing $\$ 1,000$, all society need do is impose a certain fine exceeding $\$ 1,000$; the firm will then be led to install the extinguishers as long as its assets are at least $\$ 1,000$. But if society relied on harm-based sanctions to induce the firm to install the extinguishers, the firm might not do that because of the judgment-proof problem. When monetary sanctions are not adequate to enforce regulations, however, we would expect, and we see, regulations enforced through the threat of criminal sanctions.

Finally, why is regulated activity publicly enforced? The answer seems mainly to be that individuals are often unable to identify dangerous behavior of the types at issue, for several reasons. One reason is that a person may not have the expertise necessary to evaluate risk; to evaluate the risk of the design and operation of a nuclear power plant, of methods of food preparation, of the likelihood that a type of drapery would burn and give off toxic fumes in a fire, and so forth, requires knowledge beyond that of the typical individual. A second, independent reason is that individuals may not be able to observe the behavior in question; they would not ordinarily be admitted into a nuclear power plant, a drug manufacturing facility, or a restaurant's kitchen. Hence, it seems that effort is needed to obtain information about dangerous behavior. Thus, for the general reasons furnished in section 2.4 above, public enforcement appears to be desirable rather than reliance on private enforcement actions.

3.3 Injunctions. Individuals bring injunctions for nuisances and clear, continuing threats to health or safety. We have to say why, for such behavior, it makes sense for society to make use of injunctions, that is, of prevention and act-based intervention that is privately-initiated. As with the behaviors controlled by safety regulation, a partial answer for why intervention is preventive and/or act-based may lie in the inadequacy of harm-based sanctions. A firm that fails to properly maintain a holding pool containing toxic waste might not be able to pay for harm done, so that sanctions for harm might not lead it to take ameliorative action, making an 
injunction a socially desirable method of controlling its behavior. However, one can imagine many circumstances in which parties bring injunctions but in which the judgment-proof problem is not clearly at issue, such as injunctions against the making of noise. ${ }^{7}$ In any case, it appears that the areas of application of injunctions are such that the information the courts possess gives them confidence that enjoined activity is undesirable. Indeed, substantial information is provided to the courts by the fact that enjoined activity is often of a continuing character, and that it is sometimes activity that has produced harm in the past, as when a person has a history of making noise or of generating noxious odors.

That the behaviors at issue should be controlled through privately-initiated legal action, rather than through public enforcement effort, is explained by the fact that the types of behavior that are usually enjoined are a subset of behaviors that can be observed and recognized as dangerous by individuals. There are many types of dangerous activities that individuals will come to recognize, such as the presence of vicious dogs, noxious odors, and so forth; virtually by definition, nuisances are activities of which we are aware, for they bother us. Individuals are able to recognize these acts because of where they occur, because little or no technical knowledge is needed to understand the danger they present, and for other reasons. For such activities that individuals are able to recognize, society benefits by allowing the individuals to bring injunctions to prevent harm; it would be a social waste to have public enforcement agents expending effort to find the nuisances and other dangerous conditions that individuals naturally recognize themselves. $\quad 3.4$ Contract law. The nature of contract law is, of course, that private parties can bring suit for relief only when harm is done. Why it makes sense to govern behavior in contracts by means of harm-based legal intervention is in part that this will generally be enough to guarantee socially desirable behavior. Usually the use of ex post sanctions will be sufficient to accomplish the purposes of contract law. Indeed, as argued in the chapters on contract law, the payment of expectation damages (or whatever the measure is that the parties specify) will accomplish the purposes of the parties. The judgment-proof problem will be substantially mitigated by the fact that the parties tend to know about each other; if one contracting party believes that the other could not pay damages and would not have another reason to perform (such as a desire to maintain his reputation), the first party might choose not to contract or to take other steps to protect himself (perhaps not rely very much on performance).

To continue, let me suggest why a system under which the state intervenes in contractual relations earlier than when harm is done, earlier than when a breach occurs, would be unworkable. The primary reason is that the state does not have enough information to know when a party is likely to commit a breach, and breach is often an event that occurs suddenly, for instance when a supplier decides to sell to another party, or does not deliver something on time because he neglects to ship it on the planned date. Indeed, it requires a real mental effort even to conceive of a world in which there is significant legal intervention before breaches of contract actually occur.

Regarding the form of remedy, several points should be made. As noted above, the use of money damages for breach is generally beneficial for the parties. This is not only because the

\footnotetext{
${ }^{7}$ Here, though, it is possible that tort damages for noise are too low, for doctrinal reasons, effectively rendering harm-based sanctions inadequate, in which case it might be said, taking the inadequacy of damages as a constraint, that injunction is desirable to control behavior.
} 
system of money damages tends to induce performance, but also because it gives those with an obligation to perform an escape hatch; it allows them to commit breach when performance is very expensive or when highly favorable alternative opportunities present themselves. The mutually beneficial nature of the escape hatch provided by breach and payment of money damages would not function well if the form of sanction for breach were imprisonment (or another costly nonmonetary sanction). For then, when breach occurred, the costs of the sanction would be borne, to the detriment of both the parties. (The victim of the breach would not only receive no compensation, he would have to pay in the form of a higher price for the anticipated losses the party in breach would suffer.) Thus, money damages rather than imprisonment are the best form of sanction for breach. It remains to account, though, for the use of specific performance as a remedy for breach. As the reader will recall from chapters 15 and 16, specific performance is desirable for the parties only in situations in which an escape hatch is not mutually advantageous for the parties (typically, for contracts to transfer property, like land, that already exists). Thus there is no conflict between what was just said about the undesirability of costly nonmonetary sanctions for breach when an escape hatch is mutually desirable and the use of specific performance in certain contractual contexts.

Finally, that it is rational for legal intervention for breach to be privately initiated by the victims of breach is virtually self-evident. When individuals make contracts, they know each others' identity, and when one of the parties defaults on his obligation, the other automatically knows of it. Hence, society ensures that this information about breach is reported by allowing the victim of a breach to collect or to obtain specific performance. It would be a wasteful folly to have public enforcement agents attempt to identify those who made contracts and whether they were living up to them in a world where victims of breach were not given redress and would not be motivated to report breach (except out of irritation or anger).

3.5 Criminal law. I now want to explain why the category of acts that we treat as crimes -- murder, robbery, theft, and so forth -- are controlled with the nonmonetary sanction of imprisonment, whether or not harm is done, and through the use of public enforcement. This discussion is relatively brief given the consideration of aspects of this question in section 4 of chapter 24 . As emphasized there, the use of monetary sanctions alone would be grossly inadequate to control the acts in the core area of crime. The types of individuals who commit crimes often have little or no assets and are often unlikely to be identified or, at least apprehended, by private parties for having done harm. Car thieves, for example, tend to have little personal wealth and most instances of car theft do not result in sanctions. If car theft and most other acts in the core area of crime were to be punished solely by monetary sanctions, deterrence of these acts would be terribly inadequate.

The problems of achieving deterrence for criminal acts are sufficiently great that society cannot rely merely on sanctions for the doing of harm, and will find it desirable to impose sanctions when acts are committed that are potentially very harmful even though they do not result in harm, or in much harm, in a given instance. This is why it is rational for society to punish the whole class of attempts, and also why society punishes acts like carrying certain types of concealed weapons. These acts are very harmful in an expected sense, so it may well be rational for society to punish them. To restrict sanctions only to acts where a person succeeds in doing harm would be undesirable because of the inadequacy of that policy as a deterrent. However, society does tend to draw a line and not to punish acts that are not associated with 
sufficiently large expected harm. Thus, if a person is discovered only at a very early stage of an attempt, or if he is found to have only a concealed pocket knife, he might well not face sanctions. In such a fashion, society addresses the problem of lack of information about dangerousness, at the same time that it augments deterrence by penalizing acts before harm is done if the expected harm is large enough.

That society employs public enforcement agents in the area of criminal behavior is chiefly due to the fact that it takes effort to identify and to capture those who commit criminal acts. Hence, for the general reasons advanced earlier, it makes sense to use public enforcement agents to discover and apprehend criminals. In addition, those who commit criminal acts would often retaliate against those who seek to sanction them; this could be problematic for a system that depended on private enforcement (and is itself a difficulty for public enforcement when the cooperation of witnesses is needed).

3.6 Joint use of methods of legal intervention. Much behavior is controlled by several methods of legal intervention. For example, many harms are controlled both by tort law and safety regulation, and most crimes are also torts. At the most general level of explanation, joint use of methods of legal intervention would seem socially desirable, for we would expect that gaps in the effectiveness of one method of intervention would often usefully be filled by other methods of intervention. Let us consider more specifically, although very briefly, the benefits of joint use of safety regulation and tort law, and of criminal law and tort law, to demonstrate the value of analyzing joint use of methods of control from the perspective of this chapter.

Safety regulation and tort law. One observes that many harms are controlled both by safety regulation and by tort law. For example, harms due to fire are controlled both by regulation dealing with such conduct as installation of sprinkler systems and fire exit signs, and harms due to fires are also affected by the possibility of suits. What we need to explain is why neither safety regulation alone nor tort liability alone is sufficient to control harm due to fire (let me focus on this example here).

The answer as to why it is not advantageous to use the liability system alone is essentially what was said to be the reason for use of safety regulation in the first place: that liability may fail to deter where parties are judgment proof or would not be identified as the authors of harm. Some parties will thus not be deterred by the threat of liability for causing harm (consider a restaurant with meager assets), implying that it will be useful to have safety regulation to induce or to force these parties at least to install sprinkler systems and fire extinguishers to reduce fire risks. Safety regulation, in other words, operates as a kind of backstop to the liability system, when that system fails adequately to deter.

With regard to the converse question, why is not safety regulation alone used to control fire risks, the kernel of the explanation concerns the drawback of safety regulation that was emphasized above, that desirable regulation requires government to obtain information that it is unlikely to possess for many acts affecting risk. Government may be able to determine that certain risk-reducing steps, such as installing sprinkler systems, are worth taking, and may be able to monitor them relatively cheaply, but there is much behavior that government cannot assess with respect to its social desirability or that it cannot easily regulate. Consider whether restaurants keep flammable materials away from stoves, whether oily rags that could catch on fire are left in storage closets, and the like. The use of the liability system gives the many actors who do have assets sufficient incentive to take such precautions as to remove oily rags and keep 
flammables in safe places. This is why it is rational for the liability system to be used to complement safety regulation, and why compliance with safety regulation is not a general defense to liability in a tort action.

Criminal law and tort law. Most crimes that cause harm are also torts, for which victims can collect against injurers, and the question is, why should this be so? The primary answer involves the point that monetary sanctions are less expensive than imprisonment. If society determines that a person has committed a crime, then deterrence of this type of act can be increased inexpensively, from society's point of view, by imposing monetary sanctions. ${ }^{8}$ Giving victims a right to sue in tort is one way of accomplishing the object of augmenting imprisonment with monetary sanctions. However, it might be asked why that should be done using the tort system rather than solely by imposition of fines. Possible answers are that when victims can collect, rather than the state, their incentives to supply information to the state and to cooperate in prosecution are enhanced, and that this affords them with compensation if uninsured. In any case, the state also has the option to impose fines, and sometimes does so.

3.7 Possibly beneficial changes in the structure of legal intervention. Although I have suggested that important aspects of the gross structure of our system of legal intervention may be seen as rational, there are significant benefical changes that could be pursued, and I mention here a few possibilities. One is that greater use of financial rewards for those who report on infractions of law seems promising; it seems that public enforcement could be aided significantly by paying private actors for information. The basis for this suspicion is that private actors, especially those working within organizations, often possess information about violations of law; and to offer this information, they need to receive significant rewards (so-called whistle-blower rewards). Another general avenue for improvement would be to reduce the amount of regulation, given that it requires regulators to have more information than they can be expected to possess, and to substitute for regulation publicly-imposed sanctions based on harm: namely, fines for harm (or fines inflated by the probability of discovery of harm); and corrective taxes for expected harm. Although fines are in fact employed, of course, that is done mainly to enforce regulatory requirements rather than to impose a bill on injurers equal to harm; and corrective taxes for expected harm are rarely used. These methods of intervention offer great advantages over regulation because they do not require the state to determine optimal behavior.

\section{Remarks: Incompletness of Analysis}

There are several important respects in which the discussion here is incomplete, and I will comment briefly on them. The first is that, although I discussed the structure of legal intervention, I did not address the closely-related issue of the overall scope of legal intervention: that is, which behaviors and conduct are desirable to control legally and which are not. The answer to this question depends in part on the social costs associated with legal intervention and on extra-legal mechanisms of social control, notably, extra-legal social sanctions associated with loss of reputation, and also the internally felt sanctions associated with breach of norms of morality. The stronger are these social sanctions and the force of morality, the lesser is the need

\footnotetext{
${ }^{8}$ Recall the point made in sections 3 and 4 of chapter 21 , that it is optimal to impose monetary sanctions equal to wealth before imposing imprisonment sanctions.
} 
for legal sanctions. These issues will be discussed in part in chapter 27 below.

A second aspect of incompleteness of the treatment here is that some significant forms of legal intervention in our affairs were not noted or barely so. For example, I did not analyze corrective taxation, and I did not discuss declaratory actions (such as the granting of marriage licenses).

A third element of incompleteness is that I did not consider the protection of risk-averse individuals against risk as a social goal. This was a simplification that I think is sensible to make because, as mentioned several times in this book, insurance is widely available on markets, and the state can always provide public insurance coverage against a risk if for some reason individuals do not purchase it and it is deemed socially desirable. Hence, it does not seem that satisfying insurance needs should be an important consideration in the choice of methods of legal intervention.

A fourth element of incompleteness is the omission of income distributional equity as a social goal. As with omission of insurance needs, this was a simplification that I believe was reasonable to make. The reason, which has been mentioned above and will be amplified in chapter 28 below, is that income distributional equity can be pursued directly through the use of the income tax and public welfare systems. Thus, altering the design of the legal system proper to achieve distributional equity might needlessly compromise achievement of other social goals.

Note on the literature. A number of articles analyze particular issues concerning the optimal structure of law from an economic perspective. See in particular Calabresi and Melamed (1972) and Kaplow and Shavell (1996b), emphasizing tort law/liability rules versus property rules/injunctions; Posner (1985b) and Shavell (1985a) on criminal law and tort law; Shavell (1984b,c) on tort law/liability rules versus regulation; and Becker and Stigler (1974), Landes and Posner (1975), and Polinsky (1980a) on public versus private enforcement of law. Also, as noted, my article Shavell (1993 ) sketches optimal legal design along the lines of this chapter. In all, however, the analysis of the structure of law is at an early stage of development. ${ }^{9}$

${ }^{9}$ See also Polinsky 1980a on tort law/liability rules versus property rules/injunctions; Kolstad, Ulen, and Johnson 1990 and Wittman 1977 on liability rules versus regulation; Baumol and Oates 1988, Kaplow and Shavell 2002c, and Weitzman 1974 on corrective taxation versus regulation. 


\section{References}

Baumol, William J., and Wallace E. Oates. 1988. The Theory of Environmental Policy. New York: Cambridge University Press.

Becker, Gary S., and George. J. Stigler. 1974. Law Enforcement, Malfeasance, and Compensation of Enforcers Journal of Legal Studies 3:1-18.

Calabresi, Guido, and A. Douglas Melamed. 1972. Property Rules, Liability Rules, and Inalienability: One View of the Cathedral. Harvard Law Review 85:1089-1128.

Kaplow, Louis, and Steven Shavell. 1996b. Property Rules versus Liability Rules: An Economic Analysis. Harvard Law Review 109:713-90.

----- 2002c. On the Superiority of Corrective Taxes to Quantity Regulation. American Law and Economics Review 4:1-17.

Kolstad, Charles D., Thomas S. Ulen, and Gary V. Johnson. 1990. Ex Post Liability for Harm vs. Ex Ante Safety Regulation: Substitutes or Complements? American Economic Review 80:888-901.

Landes, William M., and Richard A. Posner. 1975. The Private Enforcement of Law. Journal of Legal Studies 4:1-46.

Polinsky, A. Mitchell. 1980a. Private versus Public Enforcement of Fines. Journal of Legal Studies 9:105-27.

Posner, Richard A. 1985b. The Federal Courts: Crisis and Reform. Cambridge, Mass.: Harvard University Press.

Shavell, Steven. 1984b. Liability for Harm versus Regulation of Safety. Journal of Legal Studies 13:357-74.

----- 1984c. A Model of the Optimal Use of Liability and Safety Regulation. Rand Journal of Economics 15:271-80.

----- 1985a. Criminal Law and the Optimal Use of Nonmonetary Sanctions as a Deterrent. Columbia Law Review 85:1232-62.

----- 1993. The Optimal Structure of Law Enforcement. Journal of Law and Economics 36:25587.

Weitzman, Martin L. 1974. Prices vs. Quantities. Review of Economic Studies 41:477-91.

Wittman, Donald. 1977. Prior Regulation versus Post Liability: The Choice Between Input and Output Monitoring. Journal of Legal Studies 6:193-211. 